\title{
2010: the year in which ...
}

BY ADAM MANN

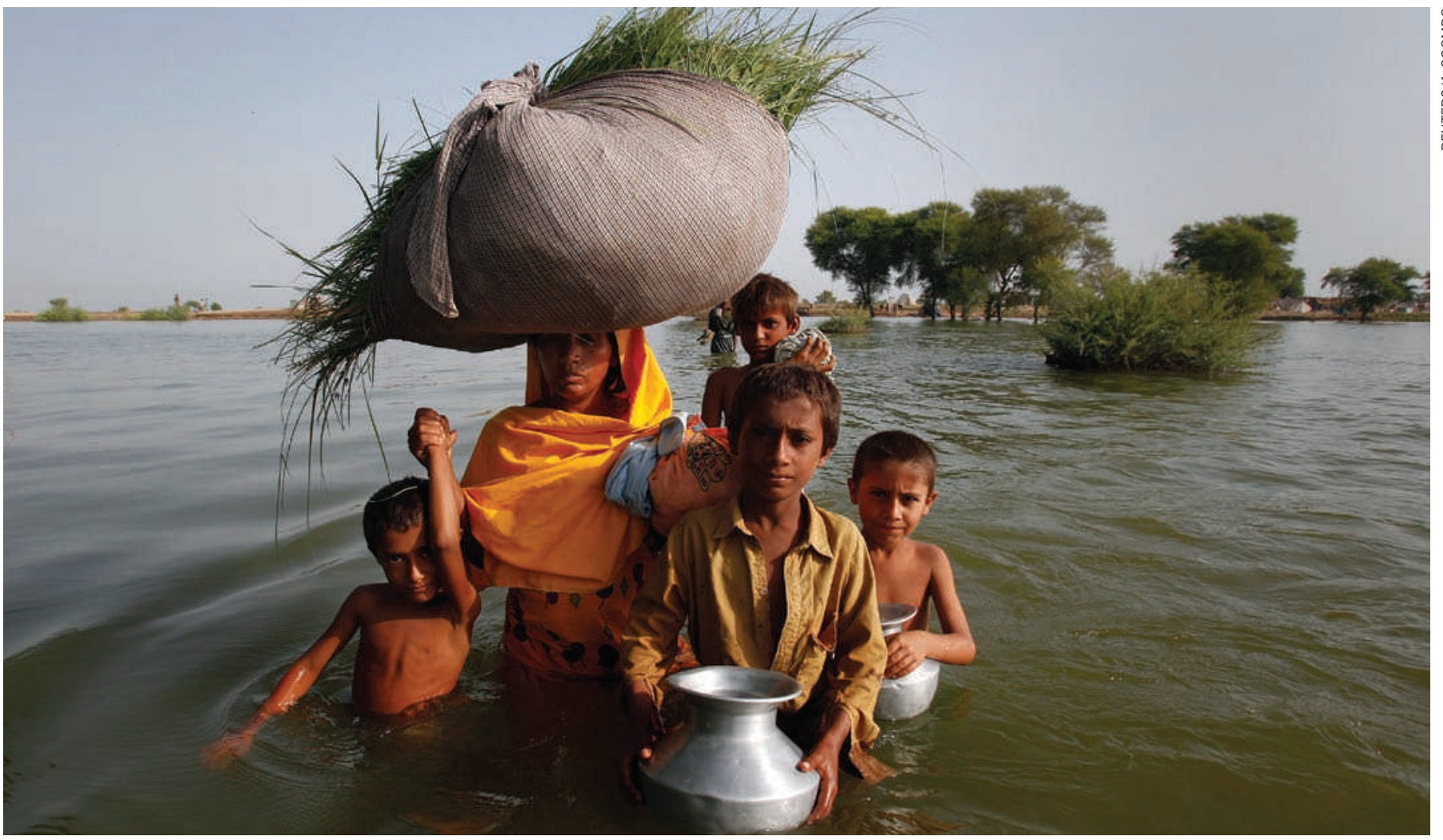

In a year marked by environmental disasters, Pakistan was perhaps hardest hit, as a flood affected an estimated 20 million people.

\section{Natural disasters pummelled Earth}

In January, a magnitude-7.0 earthquake struck Haiti - the most violent such event to strike the impoverished nation in a century. An estimated 230,000 people died and a further 1 million were left homeless. Other earthquakes, including a magnitude-8.8 quake in Chile in February and a magnitude 7.1 in New Zealand in September, also caused widespread damage, but smaller death tolls. Ash from the eruption of volcano Eyjafjallajökull in Iceland grounded commercial flights across Europe for a week in April, stranding thousands of travellers (see 'Quotes of the year'). And unusually intense rains related to the La Niña cooling of the Pacific Ocean flooded one-fifth of Pakistan and affected an estimated 20 million people. The weather pattern was also implicated in a drought in Russia as the country experienced the hottest summer in its recorded history, unleashing hundreds of deadly wildfires.

\section{Ancient kissing cousins were found}

Two reports suggested that modern man carries genes from extinct branches of the human family tree. The question of whether Neanderthals, which went extinct about 30,000 years ago, ever mated with humans had been hotly debated, but evidence had been sparse. Even the sequencing of the Neanderthal genome in 2009 provided no definitive evidence. On 7 May, researchers announced the results of a genetic analysis of nearly

\section{DNATURE.COM} Read Nature's special section reviewing the year. www.nature.com/2010
2,000 people from around the world, which yielded signs of gene flow between Neanderthals and Homo sapiens around the time that modern humans first migrated out of Africa some 50,000-60,000 years ago. Evidence of more recent mixing appears in this issue of Nature. A genome extracted from a 30,000-50,000 year-old finger bone found in a Siberian cave not only attests to the existence of another hominin group, but suggests that the group interbred with a particular band of human migrants that were ancestors of today's Melanesians. SEE PP.1012, 1044 \& 1053

\section{Doctors gained new weapons against HIV}

In July, researchers revealed that an antiretroviral microbicide gel cut HIV infection by up to $54 \%$ in women who used it regularly. The findings, which came from a study of about 900 South African women at high risk of infection, gave hope to those seeking to bring down the rate of HIV infection in sub-Saharan Africa, where the majority of new cases occur. Another breakthrough came in November, when a study of nearly 2,500 men showed that the antiretroviral drug Truvada is an effective preventative measure. Among men who have sex with men, those who took the drug consistently lowered their risk of acquiring the virus by $73 \%$.

\section{Scientists unveiled a synthetic genome}

In a bold step towards designer life, researchers at the J. Craig Venter Institute in Rockville, Maryland, announced on 20 May that an artificial genome inserted into a bacterium had successfully commandeered the cell and commenced replication. Using the genome from the bacterium 
Mycoplasma mycoides as a blueprint, Daniel Gibson and his colleagues at the institute assembled their synthetic genome in a yeast cell and transplanted it into the closely related species Mycoplasma capricolum. Although the 1.1-million-base-pair sequence was a near duplicate of M. mycoides, it included four special 'watermark sequences' to distinguish it from the original, as well as a hidden code that, once deciphered, included a website address and several famous quotes. Some researchers considered the move to be a significant advance over conventional genetic engineering, although others argued that scientists are a long way from being able to design and construct novel bacteria from scratch. If the technology advances sufficiently, many hope that artificial life can be used for a variety of tasks, including carbon sequestration, biofuel production or the clean-up of chemicals.

\section{Oil gushed into the Gulf of Mexico}

On 20 April, an explosion on BP's Deepwater Horizon oil rig killed 11 workers and precipitated one of the worst oil spills in history. By August, the damaged well had dumped nearly 5 million barrels of oil into the Gulf of Mexico, spewing as much as 62,000 barrels a day at its peak. Engineers capped the well on 15 July, although it was not permanently sealed with cement until 19 September. During the spill, researchers detected large plumes of oil below the water's surface. In its aftermath, debate continued over where all the oil had gone. An estimate released by the US National Oceanic and Atmospheric Administration, which suggested that about half of the oil had dispersed, dissolved or evaporated, was roundly criticized as too optimistic. Later, researchers discovered a layer of precipitated oil on the sea floor. SEE P. 1024

\section{Climate-change policy stalled}

Efforts to confront climate change stumbled early on, but finished the year on a positive note. In January, the Intergovernmental Panel on Climate Change, chaired by Rajendra Pachauri, was embarrassed to learn that a 2007 report had erred when it stated that all glaciers in the central and eastern Himalayas could melt by 2035 . The claim had not come from peer-reviewed scientific literature, but from a comment by Indian glaciologist Syed Hasnain in a 1999 article in New Scientist, and the mistake provided fodder for climate-change sceptics. Over the summer, three US senators - John Kerry (Democrat, Massachusetts), Joseph Lieberman (Independent, Connecticut) and Lindsey Graham (Republican, South Carolina) - failed to push through a bill that would have instituted a cap-and-trade system for domestic industry's carbon emissions, even though the House of Representatives had approved a similar bill. The end-of-the-year United Nations Framework Convention on

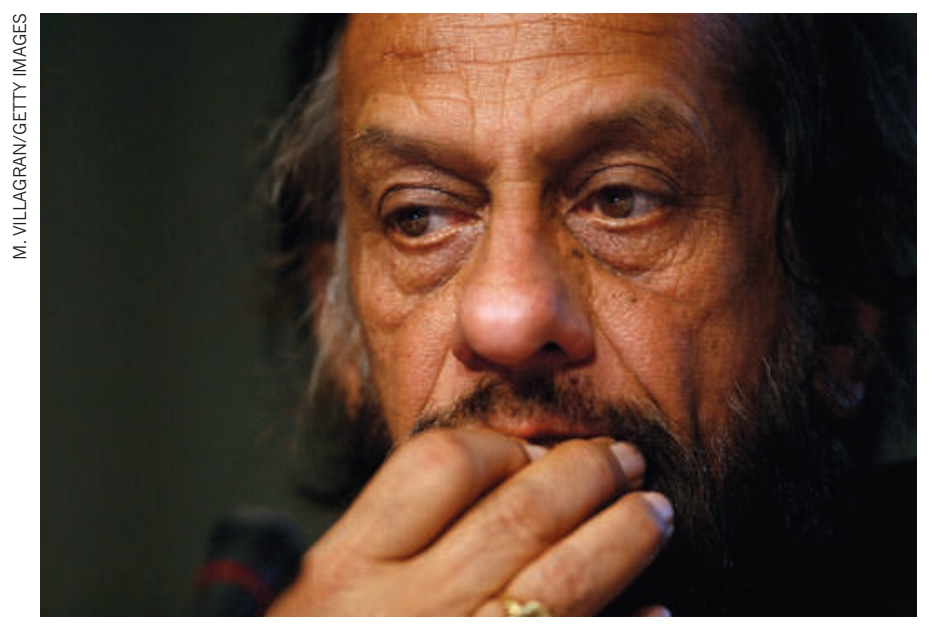

Rajendra Pachauri felt the heat in 2010.

\section{Quotes of the year}

\section{"The first self-replicating species we've had on the planet whose parent is a computer."}

\section{Craig Venter describes the artificial bacterium created at his lab. Source: New York Times \\ "If we can turn the oil into smoke, we'll all be happy."}

Ed Levine, National Oceanic and Atmospheric Administration scientific support coordinator for the Deepwater Horizon spill effort, on burning the oil in open water before it reaches land. Source: Nature

"When I got the telephone call, I thought, 'Oh shit!' The second thought that came to my mind: 'Oh dear, I will not win many more prizes." "

Andre Geim describes how he felt after learning he would share this year's Nobel Prize in Physics.

Source: Nature's The Great Beyond blog

\section{"My own personal feeling is that the chances of life on this planet are $100 \%$."}

Astronomer Steven Vogt on his team's discovery of an extrasolar planet orbiting in the 'habitable zone' of the star Gliese 581. Other scientists have been unable to find evidence for the planet.

Source: Daily Telegraph

"We checked every option, but there were no boats and no train tickets available. That's when my fabulous assistant determined the easiest thing would be to take a taxi."

Comedian John Cleese, who made the journey from Oslo to Brussels following the eruption of Eyjafjallajökull in said taxi, at a cost of 30,000 Norwegian kroner (US $\$ 5,000$ ).

Source: Sky News Online

\section{"There might be some interesting} application, but frankly I don't have one now."

Physicist Andrew Cleland speaks about placing a 30-micrometre mechanical paddle into a superposition of quantum mechanical states so that it was simultaneously vibrating and not vibrating. Source: Nature

\section{"They have managed to reach an agreement by moving the goalposts closer to the ball."}

David Victor, director of the Laboratory on International Law and Regulation at the University of California, San Diego, discusses the international climate agreement reached in Cancún.

Source: Nature 
- Climate Change meeting in Cancún, Mexico, brought some good news when participants agreed to set a goal of limiting average warming to $2{ }^{\circ} \mathrm{C}$ above preindustrial levels. Building on the ultimately unsuccessful Copenhagen Accord from last year, countries also created an international tracking system to report progress on lowering emissions.

\section{Japan's space agency had a hit and a miss}

On 16 November, researchers confirmed that micrometre-sized grains found in the Japan Aerospace Exploration Agency's Hayabusa spacecraft were authentic asteroid dust. The mission, which gently kissed the surface of the Itokawa asteroid twice in November 2005, is the first to retrieve asteroidal material and return it to Earth for study. A month later the agency experienced a setback when its Akatsuki spacecraft failed to enter orbit around Venus, instead sailing past the planet into interplanetary space. Akatsuki, which would have mapped Venus using infrared cameras that can peer beneath its dense cloud layer and search for evidence of recent volcanic activity, will have to orbit the Sun and wait six more years for another try.

\section{Stem-cell research rode a roller coaster}

US scientists were jolted on 23 August when federal district court judge Royce Lamberth placed an injunction on federally funded human embryonic stem-cell research. The move also overrode the March 2009 executive order of US President Barack Obama mandating the National Institutes of Health to develop a policy for the approval of new stem-cell lines, which had been prohibited under the administration of George W. Bush. The injunction was to remain in force until Judge Lamberth decided whether the research violates the Dickey-Wicker Amendment, which prohibits the destruction of human embryos in research. But on 9 September, the US Court of Appeals for the District of Columbia Circuit issued a stay on the injunction, allowing federal funding to continue until the court rules on whether Lamberth's injunction should stand. Some federal stem-cell research resumed, but scientists are braced for more setbacks. Unless federal law is changed, many say the argument will ultimately find its way to the Supreme Court.

\section{Astronomers joined the dark side}

In August, US astronomers released the Astro2010 Decadal Survey, a highly influential document that, once every ten years, recommends which astronomy and astrophysics projects NASA, the National Science Foundation and the Department of Energy should fund. Acknowledging the prospect of budget cuts during the economic downturn, the report recommended a few large, expensive projects - such as the US\$1.6-billion Wide Field Infrared Survey Telescope (WFIRST), a 1.5-metre space-based instrument that could investigate dark energy, the mysterious phenomenon that is causing the expansion of the Universe to accelerate. But November brought unwelcome news: a report commissioned by Senator Barbara Mikulski (Democrat, Maryland) concluded that the 6.5-metre James Webb Space Telescope, successor to the Hubble, would come in at least $\$ 1.5$ billion over budget and would be delayed for more than a year. This implicit expected drain on NASA's budget leaves funding for WFIRST an open question.

\section{The budget crunch hit European science}

Austerity measures across many European countries stricken by the financial crisis took a toll on scientists. The five member states contributing to CERN, Europe's particle-physics laboratory near Geneva, Switzerland, approved a plan in September to reduce contributions by

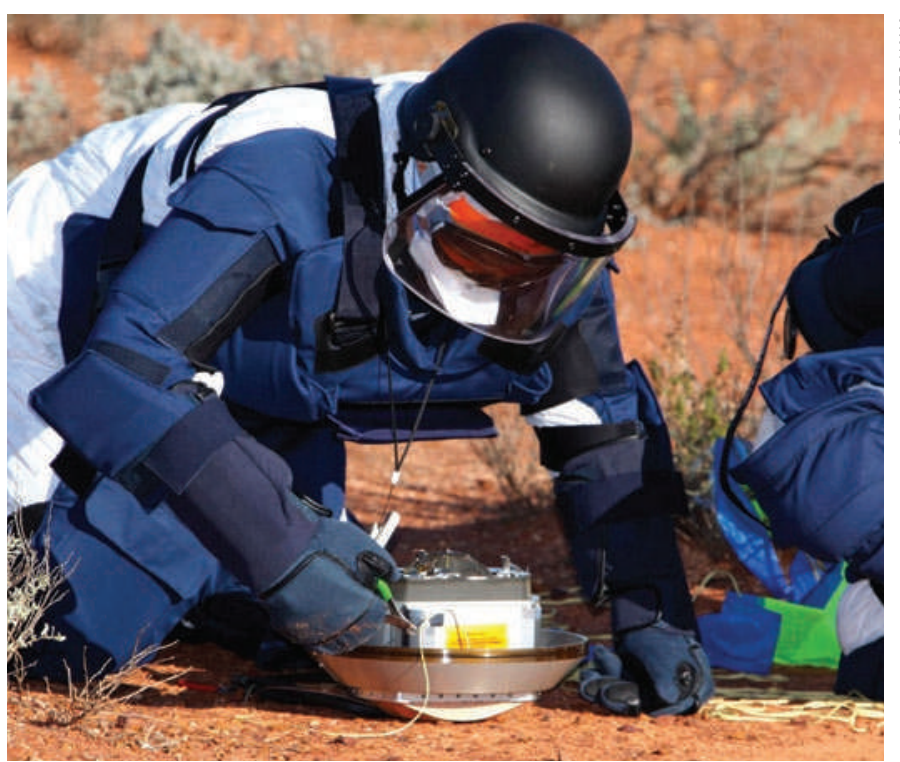

A Japanese capsule bearing asteroidal dust is recovered in Australia.

about $\$ 140$ million over the next five years and to slow down the pace of smaller research projects to protect the lab's flagship Large Hadron Collider, the world's largest particle accelerator. And Italy and Britain said they will temporarily reduce their contributions to the European Synchrotron Radiation Facility in Grenoble, France. Other countries, looking to slash their budgets, announced freezes or reductions in scientific investments; for example, the Spanish government's expenditure in research and development will drop by $8.37 \%$ next year. In October, UK scientists fought back against the funding cuts, rallying to protest in London. Eventually, the British government decided not to reduce science spending and agreed to protect the $£ 4.6$ billion (US $\$ 7.3$ billion) core science budget over the next four years. SEE P. 1010

\section{Arsenic-based life was discovered. Or not.}

A cryptic announcement from NASA in November said that the agency had important astrobiology news, leading many to speculate that it was set to unveil extraterrestrial life. Instead, during a media conference on 2 December, researchers announced the discovery of ordinary earthly bacteria from Mono Lake in California that seemed to do something extraordinary - use arsenic as a building block for DNA and proteins, in place of the phosphorus relied on by other organisms. But as soon as the unprecedented finding was made public, it drew sharp criticism from the scientific community. Biochemists took to the blogosphere, attacking the methodology and assumptions of the original research and provoking a flurry of articles in the media. Further work will be needed to settle whether the bacteria actually do use arsenic in their biochemistry as opposed to just cleverly thwarting its toxic effects.

\section{A morality expert was accused of mischief}

In August, Harvard University found that Marc Hauser, a leader in the field of animal and human cognition, had committed eight counts of scientific misconduct. Hauser studies the evolutionary origin of characteristics such as morality, language and mathematical ability, and his work has been profiled in many news outlets, such as The New York Times and the Wall Street Journal. Many scientists in the field called on Harvard to release the details of its investigation, saying that they could affect any research that uses Hauser's as a basis. As yet, Harvard has not done this. Hauser has retracted or amended at least three papers, which appeared in Cognition, Proceedings of the Royal Society and Science, respectively. 